\title{
КОМПЛЕКСЫ МЕДИ КАК ПРОТОТИП ДЛЯ ХЕЛАТИРОВАНИЯ ${ }^{67} \mathrm{CU}$
}

\section{М.А. Орлова, ${ }^{1,2}$, Т.П.Трофимова', А.С. Золотова', А.П. Орлов'}

${ }^{1}$ Химический ф-т Московского государственного Университета им. М.В. Ломоносова, 119991, Россия, Москва, Ленинские горы, д. 1, стр. 3.

${ }^{2}$ Кафедра биохимии ЛФ Российского национального исследовательского медицинского Университета им. Н.И. Пирогова, 117997, Россия, Москва, ул. Островитянова, 1.

DOI: 10.19163/MedChemRussia2021-2021-119

E-mail: orlova.radiochem@mail.ru

Создание радиофармпрепаратов является одним из приоритетных направлений современной медицины. Радионуклиды меди: ${ }^{64} \mathrm{Cu} и{ }^{67} \mathrm{Cu}-$ представляют собой пример удачных диагностического и терапевтического радионуклидов. Поэтому их хелатирование и таргетная (пролонгированная) доставка представляют огромный интерес. Нами были получены и исследованы комплексы меди с 2-аминопиримидином ( $\left.\mathrm{L}^{1}\right)$ и N-(5,6-дигидро-4H1,3-тиазин-2-ил) бензамидом $\left(\mathrm{L}^{2}\right) . \mathrm{L}^{1}$ является предшественником многих антиопухолевых агентов, $\mathrm{L}^{2}$ - проявляет цитотоксичность по отношению $\mathrm{k}$ лейкемическим клеточным линиям.

Оба лиганда способны образовывать комплексы с ионом меди, причем в зависимости от способа получения комплексы могут иметь разные кристаллические структуры и различающуюся цитотоксичность. При этом образуются комплексы следующего состава $\mathrm{L}_{2}^{1} \mathrm{CuCl}_{4}, \mathrm{~L}^{2} \mathrm{CuCl}_{2}, \mathrm{~L}_{2}{ }_{2} \mathrm{CuCl}_{2}, \mathrm{CuL}_{2}{ }_{2}$. Исследование показало, что в некоторых случаях при образовании комплекса происходит медленное восстановление Cu" в Cu' с изменением кристаллической решетки. В частности, $\mathrm{CuL}_{2}$, кристаллизующийся в моноклинной системе, способен медленно переходить в $\left[\mathrm{Cu}(\mathrm{LH})_{2} \mathrm{Cl}^{+}\left[\mathrm{CuCl}_{2}\right]^{-}\right.$, имеющий триклинную структуру. Все комплексы в разной степени проявляют антилейкемическую активность, более высокую, чем исходный лиганд. 